\title{
XXV. Experiments made during a voyage, and at bermuda, on the carbonic acid in the atmosphere
}

\author{
Lieut.-Col. Emmett
}

To cite this article: Lieut.-Col. Emmett (1837) XXV. Experiments made during a voyage, and at bermuda, on the carbonic acid in the atmosphere , Philosophical Magazine Series 3, 11:67, 225-227, DOI: $10.1080 / 14786443708649266$

To link to this article: http://dx.doi.org/10.1080/14786443708649266

册 Published online: 01 Jun 2009.

Submit your article to this journal ¿

Џ Article views: 2

Q View related articles $\sqsubset$ 


\title{
LONDON AND EDINBURGH
}

\section{PHILOSOPHICAL MAGAZINE}

\author{
A N D \\ JOURNAL OF SCIENCE. \\ [THIRD SERIES.]
}

$S E P T E M B E R \quad 1837$.

XXV. Experiments made during a Voyage, and at Bermuda, on the Carbonic Acid in the Atmosphere. By Lieur.-Col. Emmetr. Communicated by Jonn Dalton, D.C.L., \& c.

Notes on Carbonic Acid in the Atmosphere in a Voyage to Bcrmuda.

$$
\begin{aligned}
& \text { 1836, April 28. Lat. } 46^{\circ} 0^{\prime} \quad \text { Long. } 14^{\circ} 51^{\prime} \\
& \text { 29. - } 447-1821 \\
& \text { May 1. - } 4258 \div 238 \\
& \text { 3. }-429-2755 \\
& \text { 11. }-3939-374 \\
& 13 .-398-386 \\
& \text { 25. - } 3053-619
\end{aligned}
$$

Carbonic acid found in all these trials made. Lime-water was the test. The quantity apparently fluctuated, the film forming at times more rapidly than at other times; most, anparently, at the 29th of April and the 1st of May.

\section{Experiments made at Bermuda, per quantity.}

Experiment 1. Sept. 25th. A glass receiver of 3920 cubic inches, $=15.5$ gallons, was taken to the north side of the island beyond any building. Wind north; day fine; thermometer $79^{\circ}$. Into this, after well washing with rain water and collecting the air, were put 1500 grain measures of lime-water. The receiver was then well closed with a cork, and set aside.

Sept. 24, $4 \frac{1}{2}$ PoM.; therm. $82^{\circ}$. Some of the lime-water used was tested: 1500 lime-water taking 410 test sulphuric acid, the liquid would be 1.009 test. It took 330 to saturate

Third Serics. Vol.11. No.67. Sept. 1837. $2 \mathrm{G}$ 
the remaining lime-water; consequently left 80 for the carbonic acid in the air**

Experiment 2. 25th of Sept. Receiver and acid as before, but the lime-waters but 210 for neutralization. Wind strong firom S.W. ; thermometer $80^{\circ}$.

Sept. 28th. The lime-waters from the receivers took 120 grain measures for neutralization, leaving 90 for carbonic acid gas; a very nearly similar result as before.

Experiment 3. Oct. 2nd, at 5 P.M. ; wind S.W. at the cessation of a heavy gale, with much rain; therm. $78^{\circ}$, barom. $30 \cdot 00$.

Receiver and acid as before. Lime-water required 390 measures for neutralization. Tested that in receivers at 5 P.M. of the 8 th inst.; therm. $75^{\circ}$. This required 210 measures of the acid for neutralization, leaving 180 for carbonic acid, being double that before, or about 1 in 3920 .

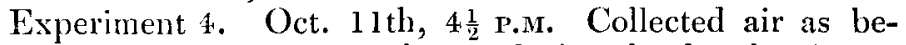
fore. There had been much rain during the day, but it was fine and calm after 3 p.M. Therm. $77^{\circ} \frac{1}{2}$. In this case the lime-water took 375 mcasures for neutralization.

Tested that in the receivers on the $18 \mathrm{th}$; therm. $75^{\circ}$. The 1500 grains in the receiver required 280 grains for neutralization, leaving $\$ 5$ for carbonic acid gas.

In the experiments 1, 2, and 4, the gas is consequently about 1 in 8000 ; and in the 3rd, 2 parts in 8000 . In the 3rd, the receiver was out during the rain, but so placed as to prevent its entrance. The air in 2 and 4 had traversed the small island of St. Davids, distant perhaps $1 \frac{x}{4}$ of a mile, thinly in habited, and thence the inlet of the sea, St. George's Harbour.

The acid was pure, brought out with me for particular experiments.

Looking to the general result, and in No. 3 the quantity bcing donde, inaccuracy of observation of the measures might possibly have led to the differences.

[Probably the whole terraqueous globe is enveloped with the same atmosphere, as is the case in azotic and oxygenous gases. 'The reason why the carboric acid is not so obvious, is its extreme minuteness. The whole quantity is not more than $\frac{1}{10} \overline{0}$ th part of the mass, or $\frac{1}{150}$ part of the volume of the atmosphere. $I$ have examined the air in a hothouse in July, with the air pent up during the night, and open in the

* The receiver was not long enougli exposed: my bottle was two gallons; it was exposed three or foul days, and agitated to exhaust the air. Contsequently ten times as much would probably be required by ten times the size of the bottle. 
usual manner during the day, and the whole quantity is the same as the carbonic acid in the atmosphere, neither more nor less.

August 9, 1837.

J. D.]

XXVI. On the Infuence of the Rotation of the Earth on the Currents of its Atmosphere, being Outlines of a general Theory of the Winds. By Prof. H. W. Dove of Berlin.*

[With a Plate.]

NOT one of the philosophers who have attempted to give a theory of the winds, has gone beyond the discussion of the regular phænomena between the tropics; for which, indeed, they cannot be blamed, as it is right in a very compli-. cated investigation to examine the most simple case first. But, on the other hand, it must seem strange that since 1685 , (in which year Ialley published his theory of the trade-winds, consequently for 150 years), not a step has been made towards a general solution of the question. The purpose of this treatise is to show, that the phænomena of the trade-winds, those of the monsoons, and the complicated relations of the winds of the temperate and frigid zones are necessary and simple consequences of the same fundamental physical causes.

The velocity of rotation of the single points of the surface of the earth is in proportion to the semidiameter of the parallel circles under which they lie; it therefore increases from the poles, where it is zero, to the equator, where it is greatest. In the state of rest the air partakes of the velocity of rotation of the place over which it is. If, therefore, from the difference of temperature, or from any other cause, it receives an impulse to flow in a parallel circle, the rotation of the earth will not have any influence upon it, because the points of the sur.. face at which the current of air arrives, have exactly the same velocity of rotation as the points whence it has proceeded. But if air is by any cause propelled from the pole towards the equator, then it comes from places whose celerity of rotation is small, to places at which it is greater. The air, consequently, then turns with less celerity to the east than the places with which it comes in contact; it therefore seems to flow in an opposite direction, viz. from east to west. The deviation of the wind from its original direction will be the greater, the more the velocity of rotation of the point of starting, by an equal progressive motion, differs from the velocity of rotation of the place at which the wind is observed, viz. the greater the difference of geographical latitude of both places. Hence follows :

* From Poggendorft's Amalen, vol. xxxri, p. 391.

$2 \mathrm{G} 2$ 